\title{
Wpływ hodowli na potencjał plonowania roślin bobowatych grubonasiennych
}

\author{
Influence of breeding on the yielding potential of grain legumes
}

\author{
Tadeusz Oleksiak $^{\oplus}$, Dagmara Bronisz ${ }^{\oplus}$
}

Instytut Hodowli i Aklimatyzacji Roślin - Państwowy Instytut Badawczy

$\bowtie$ t.oleksiak@ihar.edu.pl

\begin{abstract}
Oceniono wpływ hodowli na plonowanie roślin bobowatych i wykorzystanie istniejacego potencjału w praktyce. Analizy oparto na Wynikach Porejestrowych Doświadczeń Odmianowych roślin bobowatych prowadzonych w latach 2005-2020 oraz danych statystycznych dotyczących plonowania w warunkach produkcyjnych (GUS 2005-2020). Badano zmiany liczebności odmian rejestrowanych w Krajowym Rejestrze, plonów oraz potencjałów plonowania nasion i białka poszczególnych gatunków. Plony poszczególnych gatunków nie zmieniały się znacząco, a w przypadku łubinów w ostatnich latach można stwierdzić spadek plonów. W przypadku soi sytuacja jest odwrotna i obserwuje się wzrost jej plonowania. Po wyeliminowaniu wpływu czynników środowiskowych stwierdzono niewielkie, ale istotne wzrosty plonów nasion i białka odmian soi, grochu, bobiku i łubinów. Średni roczny przyrost plonów mieścił się w przedziale od 6,6 kg nasion na hektar dla łubinu żółtego do 40,2 kg dla soi. Analogiczne wartości wzrostu plonów białka mieściły się w przedziale od 2,7 kg dla łubinu wąskolistnego do $12,7 \mathrm{~kg}$ dla soi. Wykorzystanie istniejącego potencjału plonowania roślin bobowatych w praktyce jest lepsze niż potencjału plonowania zbóż, jednak jest to za mało dla utrzymania, a tym bardziej poprawienia ich konkurencyjności.
\end{abstract}

\begin{abstract}
Slowa kluczowe: bobowate grubonasienne, hodowla, plonowanie
The impact of breeding on grain legume yielding and utilization of the existing potential in practice were assessed. The analyses made use of the results of the Post-Registretion Variety Testing experiments of grain legumes carried out in 2005-2020 and statistical data on yielding under production conditions (GUS, 2005-2020). Changes in the number of varieties entered in the National Register, as well as in the yield and yield potential of seeds and proteins of individual species were studied. Yields of individual species have not changed significantly, and in the case of lupins a decrease in yields has been observed in recent years. Only soybean yields have increased in recent years. After eliminating the influence of weather factors, small but significant increases in seed and protein yields of soybean, peas, field bean and lupins were found. The average annual yield increase ranged from $6.6 \mathrm{~kg}$ of seeds per hectare for yellow lupin to $40.2 \mathrm{~kg}$ for soybean. Analogous values of protein yield increment ranged from $2.7 \mathrm{~kg}$ for narrow-leaved lupin to $12.7 \mathrm{~kg}$ for soybean. The use of the existing yield potential of grain legumes in practice is better than that of cereals, however, it is not sufficient to maintain, or improve their competitiveness.
\end{abstract}

Key words: grain legumes, breeding, yielding

\section{Wstęp}

Wartość roślin bobowatych, wynikająca $\mathrm{z}$ ich walorów żywieniowych, paszowych oraz środowiskowych jest szeroko udokumentowana (Florek, 2017, Jezierny, Mosenthin i Bauer, 2010, Małecka-Jankowiak, Blecharczyk, Sawińska i Waniorek, 2018, Sońta i Rekiel, 2020, Stagnari, Maggio, Galieni i Pisante, 2017). O znaczeniu i możliwości rozwoju krajowych upraw roślin bobowatych, podobnie jak każdej innej uprawy, decyduje zapotrzebowanie rynku i ich zdolność konkurowania z towarami importowanymi. Czynnikiem ograniczającym rozwój upraw jest organizacja skupu surowca, ale w głównej mierze konkurencyjny import śruty sojowej, która dominuje $\mathrm{w}$ strukturze zaopatrzenia przemysłu paszowego w Polsce. Aby to zmienić konieczna jest poprawa konkurencyjności produkcji krajowych roślin bobowatych, czego nie można osiągnąć bez poprawy plonów i opłacalności upraw. Wraz z wyczerpywaniem się możliwości poprawy wielkości i jakości plonu, na drodze doskonalenia i intensyfikacji agrotechniki, coraz większego znaczenia nabiera postęp hodowlany. Postęp hodowlany można rozpatrywać w aspekcie poprawy wskaźników jakości plonu - zawartości białka, polepszenia wartości żywieniowej, eliminacji lub zmniejszenia zawartości substancji antyżywieniowych, poprawy struktury plonu, skrócenia okresu wegetacji, ograniczenia podatności roślin na wyleganie, oraz choroby i szkodniki. Finalnym celem, do którego zmierza hodowla 
roślin bobowatych jest zwiększenie plonów nasion i białka, a także zapewnienie stabilności ich plonowania w latach (Święcicki 1993).

Celem pracy była ocena wpływu hodowli na plonowanie roślin bobowatych jak i wykorzystanie istniejącego potencjału poszczególnych gatunków w praktyce.

\section{Metodyka}

W badaniach wykorzystano wyniki Porejestrowych Doświadczeń Odmianowych roślin bobowatych prowadzonych w COBORU (Centralny Ośrodek Badania Odmian Roślin Uprawnych) w latach 2005-2020. Analizowano zmiany w liczebności odmian wpisanych do Krajowego Rejestru oraz udziału odmian polskich. Porównano zmiany plonów oraz potencjału plonowania nasion i białka dla poszczególnych gatunków bobowatych. W celu wyeliminowania wpływu czynników pogodowych analizowano również wartości odchyleń plonów odmian od plonów wzorców. Konstruowano je z odmian, wykorzystywanych w COBORU jako wzorce w Porejestrowych Doświadczeniach Odmianowych. Dla każdego gatunku przygotowano wzorzec składający się z dwóch odmian. Przy doborze odmian wzorcowych uwzględniano ich czas badania i stabilność plonowania w badaniach COBORU.

Do zaprezentowania zobiektyzowanego wpływu hodowli na plonowanie wykorzystano wskaźnik wartości odmian DYA (Differential Yielding Ability). Wskaźnik DYA pozwala ocenić plony po ograniczeniu wpływu zmiennych warunków pogodowych w poszczególnych latach. Szczegółowo opisany jest w pracach Feyerherm, Kemp i Paulsen (1989) i Krzymuski, Laudański i Oleksiak (1993). Obliczano go według wzoru:

$$
D Y A i=\frac{\sum_{r=1}^{N i}(Y i r-Y c r)}{N i}
$$

$D Y A i$ - potencjał plonotwórczy odmiany $i$

Yir - plon odmiany $i$-tej $\mathrm{w} r$-tym roku

$Y c r-$ plon wzorca $\mathrm{w} r$-tym roku

$N i$ - liczba lat badań odmiany $i$

Wyniki i Dyskusja

O zmianach w zainteresowaniu i potencjalnym znaczeniu gatunku świadczy wielkość oferty odmianowej. W ciągu analizowanego okresu 2005-2020 liczba odmian roślin strączkowych w Krajowym Rejestrze (KR) zwiększyła się o 22\%. Ponad trzykrotnie zwiększyła się liczba odmian soi i łubinu wąskolistnego, a o 57\% łubinu żółtego. Zmniejszyła się liczba wpisanych do KR odmian grochu, bobiku, łubinu białego i wyki (tab.1). W KR dominują wciąż odmiany krajowej hodowli jednak udział odmian zagranicznych wzrósł z 10 do $24 \%$. Zagranicznych odmiany to głównie odmiany soi, natomiast łubiny żółty i biały oraz wyki to wyłącznie odmiany polskie.

Najprostszym wskaźnikiem charakteryzującym intensywność prac hodowlanych jest liczba odmian rejestrowanych w KR. W latach 2006-2020 zarejestrowano łącznie 106 odmian roślin bobowatych. W początkowym okresie analizy z roku na rok zmniejszała się liczba rejestrowanych odmian. Jednak w ostatnim pięcioleciu widoczne są wyraźne efekty ożywienia i intensyfikacji prac hodowlanych, co jest zbieżne z podejmowanymi próbami stymulacji wzrostu krajowej produkcji białka roślinnego. Ponownie po okresie spadku, wzrasta zainteresowanie hodowlą bobowatych, a w Krajowym Rejestrze pojawiło się znacznie więcej nowych odmian (rys.1). Zmieniła się struktura gatunkowa rejestrowanych odmian. $\mathrm{O}$ ile wcześniej dominowały nowe odmiany tradycyjnie uprawianych w Polsce gatunków, takich jak groch i łubin (wąskolistnego i żółtego) to obecnie największy udział w rejestracji, ponad 30\% stanowią odmiany soi (rys. 2). Są to odmiany z krajowej ale przede wszystkim z zagranicznych hodowli, które coraz szerzej wchodzą na polski rynek co jest pośrednim potwierdzeniem dużego potencjału uprawy soi w naszym kraju.

Poszczególne gatunki wyraźnie różnią się uzyskiwanymi plonami, co wynika $\mathrm{z}$ różnic w potencjale plonowania, warunków glebowych, stosowanego nawożenia oraz warunków atmosferycznych i siedliskowych związanych z rejonem lokalizacji uprawy (tab.2). W latach 2006-2014 prowadzono oddzielne badania grochu siewnego przeznaczonego na cele pastewne, na stanowiskach słabszych, których średnia wartość w skali IUNG wyniosła 65,8 oraz przy niższym nawożeniu. Soję w początkowym okresie badano na południu Polski, a od 2013 roku rozszerzano je na kolejne regiony. Aktualnie badania te prowadzane są dla całego kraju. Natomiast w przypadku łubinu wąskolistnego badania początkowo prowadzono na północy, w pasie centralnym i na Podkarpaciu. Dzięki Inicjatywie białkowej COBORU możliwy był wzrost liczby badań odmianowych z roślinami bobowatymi grubonasiennymi i od 2014 roku badania praktycznie obejmowały już wszystkie regiony kraju. W przypadku bobiku w latach 2009-2016 badania obejmowały północ i południe kraju, w pozostałych latach rozłożone były na całym obszarze Polski. 
Odmiany roślin bobowatych w Krajowym Rejestrze Odmian (KR)

Varieties of legumes in the National Register (KR)

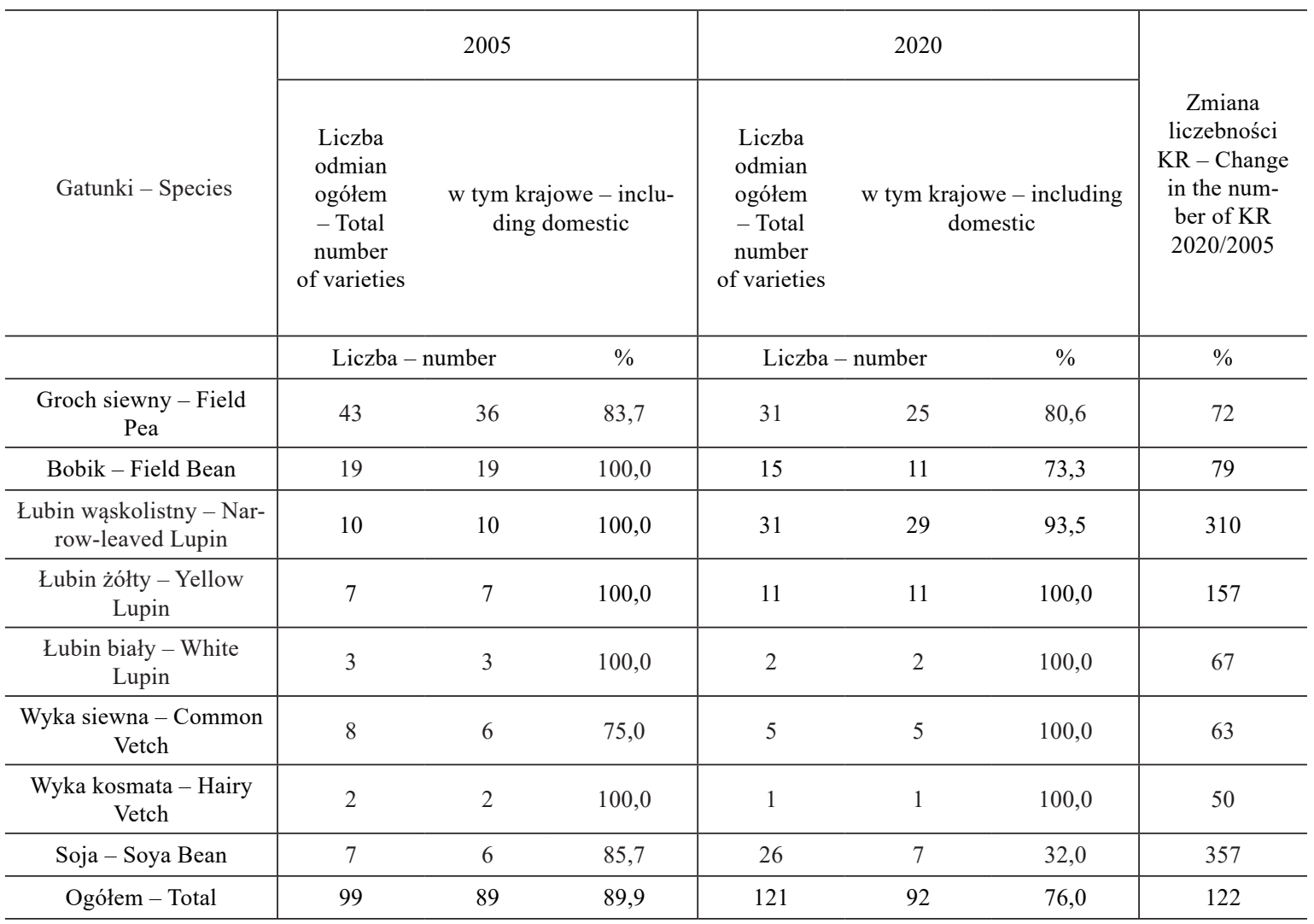

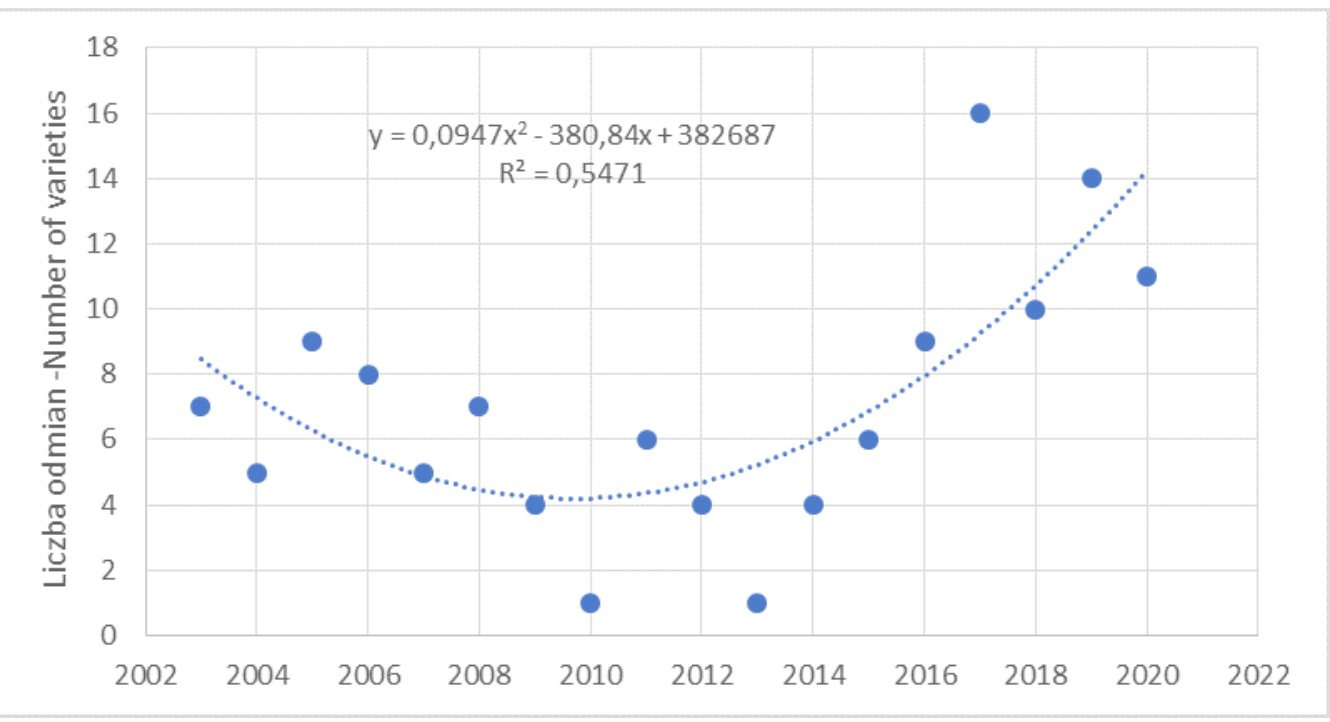

Rys. 1 Nowe odmiany bobowatych w Krajowym Rejestrze Odmian (KR)

Fig. 1 New legume varieties in the National Register (KR) 


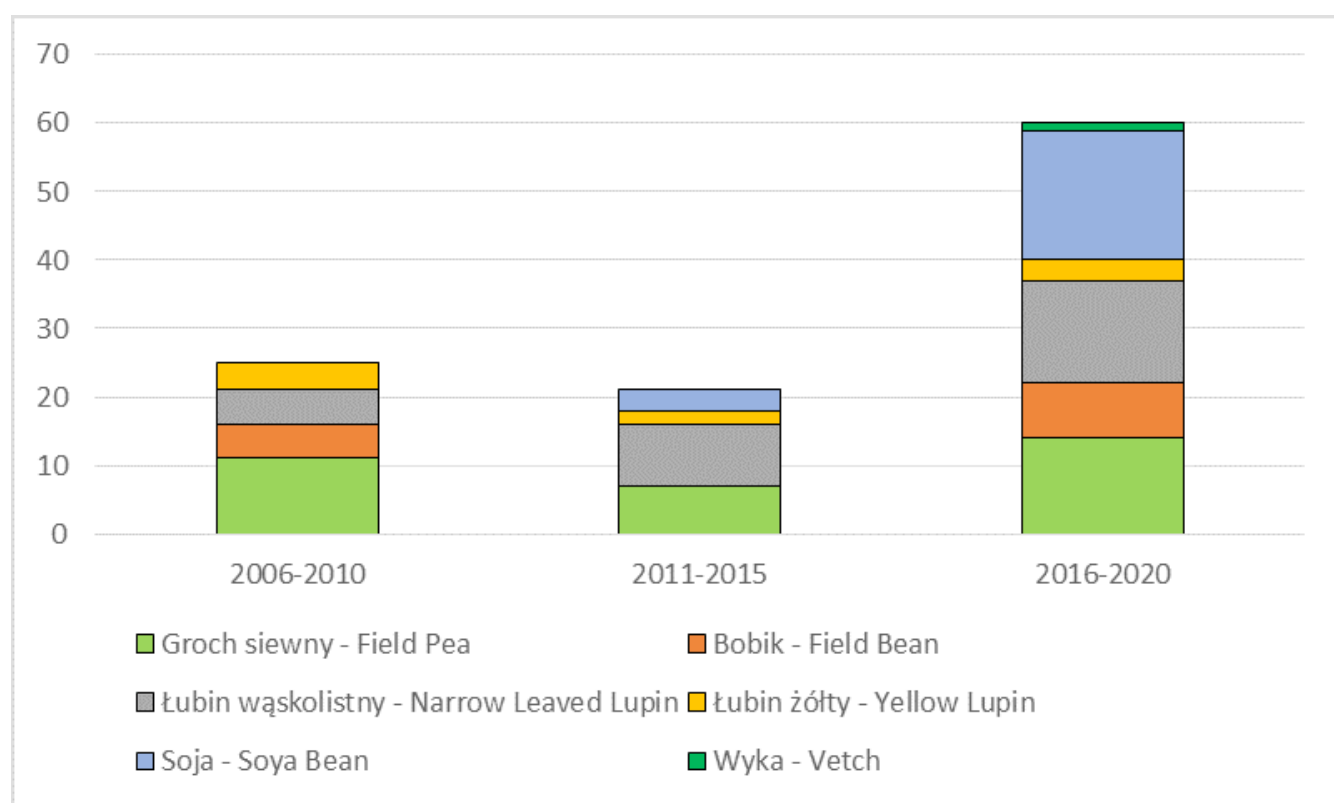

Rys. 2 Struktura gatunkowa odmian bobowatych rejestrowanych w Krajowym Rejestrze (KR)

Fig. 2 Species structure of legume varieties registered in the National Register (KR)

Średnie plony i warunki uprawy w badaniach COBORU w latach 2006-2020.

Average yields and cultivation conditions in the COBORU trials in the years 2006-2020.

\begin{tabular}{|c|c|c|c|c|c|c|}
\hline Gatunki - Species & $\begin{array}{l}\text { Plony } \\
\text { dtha }{ }^{-1} \\
\text { Yields } \\
\text { dtha }{ }^{-1}\end{array}$ & $\begin{array}{c}\text { Współczynnik } \\
\text { zmienności } \\
\text { plonów } \\
\text { Coefficient } \\
\text { of yield variation } \\
\text { [\%] }\end{array}$ & $\begin{array}{l}\text { Jakość gleby } \\
\text { skala IUNG } 100^{\circ} \\
\text { Fertilization } \\
\text { Scale acc. } \\
\text { to IUNG } 100^{\circ}\end{array}$ & $\begin{array}{c}\text { Nawożenie } \mathrm{P}_{2} \mathrm{O}_{5} \\
- \text { kghha } \\
\text { Fertilization } \\
\mathrm{P}^{2} \mathrm{O}^{5}-\text { kg ha }^{-1}\end{array}$ & $\begin{array}{c}\text { Nawożenie } \mathrm{K}_{2} \mathrm{O} \\
-\mathrm{kg} \cdot \mathrm{ha}^{-1} \\
\text { Fertilization } \\
\mathrm{K}^{2} \mathrm{O}-\mathrm{kg} \cdot \mathrm{ha}^{-1}\end{array}$ & $\begin{array}{c}\text { Nawożenie } \mathrm{P}^{2} \mathrm{O}^{5} \\
-\mathrm{kg} \cdot \mathrm{ha}^{-1} \\
\text { Fertilization } \\
\mathrm{P}^{2} \mathrm{O}^{5}-\mathrm{kg} \cdot \mathrm{ha}^{-1}\end{array}$ \\
\hline $\begin{array}{c}\text { Bobik } \\
\text { - Field bean }\end{array}$ & 44,0 & 18,0 & 79,3 & 59,9 & 111,8 & 29,0 \\
\hline $\begin{array}{l}\text { Groch siewny } \\
\text { - Field pea }\end{array}$ & 43,8 & 17,4 & 76,1 & 48,3 & 90,9 & 26,1 \\
\hline Soja - Soya bean & 28,2 & 16,7 & 77,9 & 51,0 & 88,7 & 37,2 \\
\hline $\begin{array}{l}\text { Lubin wąskolistny } \\
\text { - Narrow-leaved } \\
\text { lupin }\end{array}$ & 28,7 & 15,6 & 65,9 & 35,9 & 69,5 & 13,9 \\
\hline $\begin{array}{l}\text { Łubin żółty } \\
\text { - Yellow lupin }\end{array}$ & 18,7 & 15,4 & 61,5 & 32,5 & 64,5 & 10,1 \\
\hline
\end{tabular}

Plony nasion poszczególnych gatunków w badaniach COBORU w ostatnim piętnastoleciu przedstawiono na rysunku 3. Najplenniejszymi gatunkami są bobik oraz nieznacznie ustępujący mu groch, odpowiednie do uprawy na lepszych stanowiskach oraz warunkach intensywnych technologii. Plony gatunków odpowiednich do uprawy na słabszych stanowiskach, łubinu wąskolistnego i żółtego testowanych na glebach o niższej jakości w skali IUNG oraz obniżonym poziomie nawożenia NPK (średnio 40\%), były mniejsze odpowiednio o 35 i $58 \%$. Wśród badanych gatunków bobik i soja charakteryzowały się wyższym poziomem zmienności plonowania w latach badań.

Dobór odmian roślin bobowatych grubonasiennych i soi dostosowanych do lokalnych warunków 


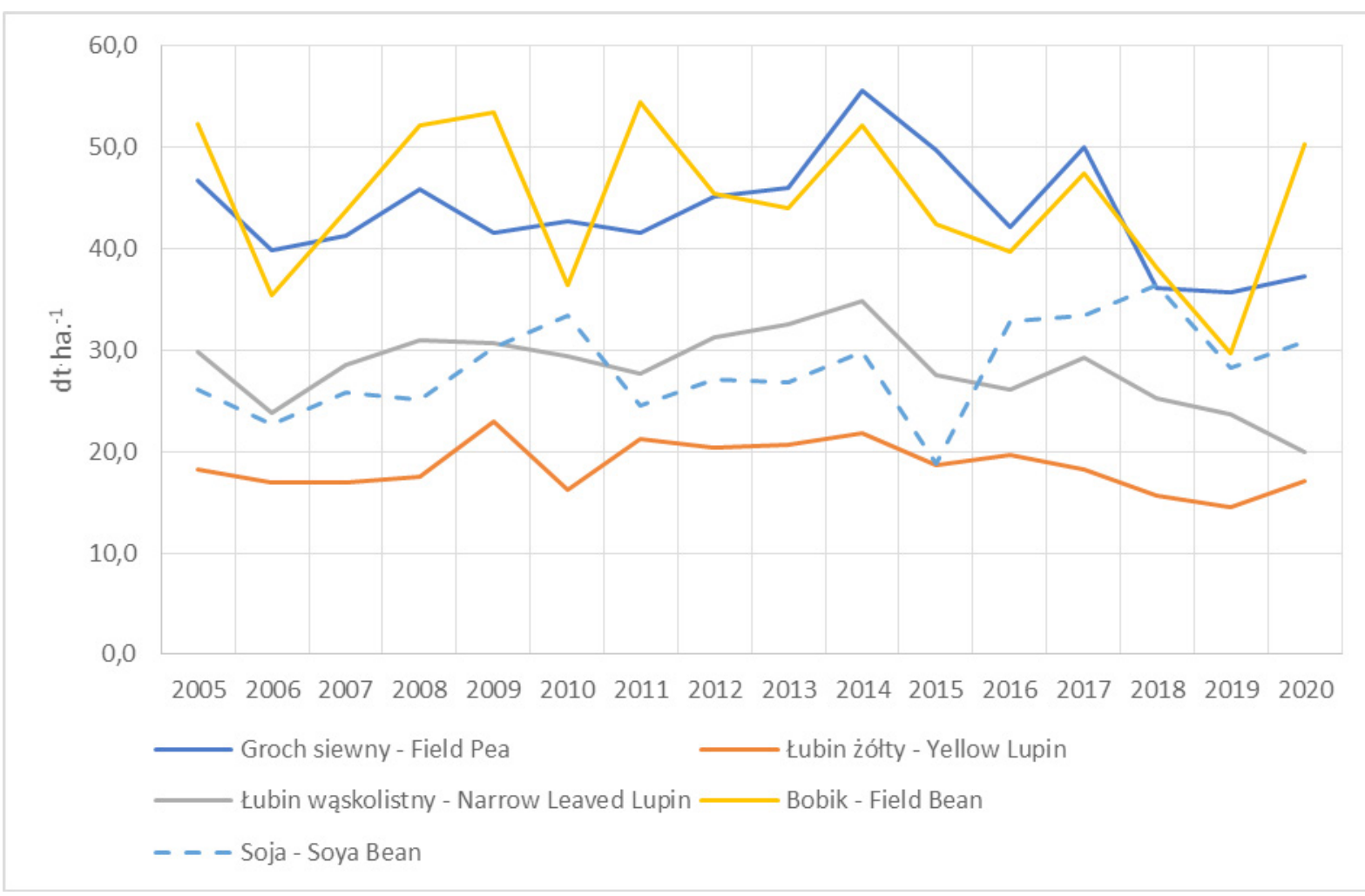

Rys. 3 Średnie plony roślin bobowatych grubonasiennych w doświadczeniach odmianowych w latach 2005-2020.

Fig. 3 Average yields of grain legumes in trials in the years 2005-2020.

środowiskowych będzie kluczowym warunkiem znaczącego rozszerzenia ich uprawy w Polsce (Gacek, 2017). Potrzebne są coraz lepiej plonujące odmiany bobowatych, które mogą skutecznie konkurować o miejsce w zasiewach jak i z importem nasion i śrut wysokobiałkowych.

Występują znaczne wahania plonów w doświadczeniach odmianowych dla roślin bobowatych w poszczególnych latach (rys.3). Generalnie nie były to zmiany pozwalające wskazać statystycznie udokumentowaną kierunkową tendencję $\mathrm{w}$ plonowaniu. $\mathrm{Z}$ perspektywy wielolecia plony poszczególnych gatunków nie zmieniły się znacząco, a w przypadku łubinów uprawianych na słabszych glebach, w ostatnich latach można stwierdzić spadek plonów. Powodem mogą być susze, bardziej odczuwalne na glebach lekkich, gdzie uprawia się łubiny. Dlatego odmiany pastewne reagują na suszę większym obniżeniem plonu nasion, niż odmiany jadalne (Kapusta, 2017). Wzrosły jedynie plony soi choć $\mathrm{i} w$ tym przypadku ich wahania były znaczne i nie można mówić o trwałym trendzie wzrostowym.

Porównując wartości plonowania uzyskane w okresie 2005-2020 z wynikami badań prowadzonych dla wcześniejszego okresu 1971-2006
(Prusiński, 2007), w których wykazano istotny wzrost plonowania dla poszczególnych gatunków $\left(57,4 \mathrm{kgha}^{-1}\right)$, można stwierdzić stagnację w plonowaniu odmian i brak istotnego postępu w hodowli bobowatych. Sytuacja ta może wynikać z wyjątkowo niekorzystnego przebiegu pogody w okresie wegetacji w ostatnich suchych latach, pogarszających się warunków uprawy jak i rozszerzania przez COBORU zakresu doświadczeń na rejony mniej sprzyjające uzyskiwaniu wysokich plonów.

W celu zobiektywizowania oceny wpływu hodowli, przeprowadzono analizę zmian plonowania poszczególnych odmian i gatunków, pozwalającą na wyeliminowanie wpływu zmiennych, niekontrolowanych czynników środowiskowych. Wyrażono je jako odchylenie od plonu wzorca uprawianego równolegle $\mathrm{w}$ latach, $\mathrm{w}$ których prowadzono ocenę. Dla wszystkich badanych odmian wyliczono wartości DYA (odchylenia plonów od plonu wzorca) charakteryzujące ich potencjał plonowania. Na ich podstawie wyliczono następnie wartości DYA charakteryzujące średnioroczne potencjały plonowania gatunków w kolejnych latach. Zmiany wartości plonów nasion i plonów białka poszczególnych gatunków opisane funkcją regresji $\left(\mathrm{R}^{2}\right)$ przedstawiono $\mathrm{w}$ tabeli 3 . 
Średnioroczny przyrost potencjału plonowania analizowanych gatunków (kg/ha) w latach 2005-2020 według danych COBORU

Average annual increase in the yielding potential $\mathrm{kg}^{-\mathrm{ha}^{-1}}$ in $2005-2020$ according to COBORU

\begin{tabular}{ccccc}
\hline \multirow{2}{*}{ Gatunki - Species } & \multicolumn{2}{c}{ Plon nasion Seed yield } & \multicolumn{2}{c}{ Plon białka - Protein yield } \\
\cline { 2 - 5 } & $\mathrm{a}$ & $\mathrm{R}^{2}$ & $\mathrm{a}$ & $\mathrm{R}^{2}$ \\
\hline Soja - Soya bean & 40,2 & 0,8037 & 12,7 & 0,8679 \\
\hline Groch siewny Field peas & 25,5 & 0,8931 & 7,5 & 0,9191 \\
\hline Łubin wąskolistny - Narrow-leaved lupin & 11,9 & 0,8961 & 2,7 & 0,9149 \\
\hline Bobik - Field bean & 8,7 & 0,6334 & 5,1 & 0,8929 \\
\hline Lubin żółty - Yellow lupin & 6,6 & 0,8964 & 3,4 & 0,8653 \\
\hline
\end{tabular}

Stwierdzono istotny wzrost plonów wszystkich gatunków. Średnie roczne przyrosty plonów $\mathrm{z}$ hektara mieściły się w przedziale $6,6 \mathrm{~kg}$ dla łubinu żółtego do 40,2 kg dla soi. Analogiczne wartości wzrostu plonów białka mieściły się w przedziale od 2,7 kg dla łubinu wąskolistnego do $12,7 \mathrm{~kg}$ dla soi (tab. 3). Należy zwrócić uwagę na wysoką dynamikę wzrostu plonowania soi uzyskanego dzięki postępowi hodowlanemu, porównywalną $\mathrm{z}$ wartościami uzyskiwanymi $w$ głównych regionach uprawy Stanach Zjednoczonych - 31,8 $\mathrm{kg} \mathrm{ha}^{-1}$ dla lat 1999-2010 (Stojšin, Matson i Leitz, 2014) czy Argentynie - 44,3 $\mathrm{kg} \mathrm{ha}^{-1}$ dla lat 1985-2015 (Felipe, Gerde i Rotundo, 2016). O ile w warunkach Stanów Zjednoczonych i Argentyny soja jest jedną z głównych upraw, to w Polsce wciąż stanowi uprawę marginalną $\mathrm{z}$ dużymi perspektywami dalszego wzrostu potencjału plonowania. Zwiększenie upraw tego gatunku i tym samym produkcji nasion będzie wiązało się ze zwiększeniem zapotrzebowania na materiał siewny, co może stać się czynnikiem pobudzającym dalsze badania i prace hodowlane ukierunkowane na otrzymanie odmian soi wysoko plonujących w warunkach glebowo-klimatycznych naszego kraju.

Wzrost plonowania bobowatych nie odbywał się kosztem zawartości białka, którego plony także wzrosły (tab.3). Przyrost potencjalnych możliwości plonowania był jednak niewielki. Jedynie wartości współczynników regresji wykazane dla plonu nasion soi i grochu były zbliżone do analogicznych wartości uzyskiwanych dla zbóż. Efektem są rosnące różnice między możliwymi do uzyskania plonami zbóż i bobowatych (rys. 4). Mimo, że potencjał plonowania roślin bobowatych w produkcji wykorzystywany jest lepiej niż potencjał zbóż (rys.5), to może być to za mało dla utrzymania a tym bardziej poprawienia konkurencyjności, co jest niezbędnym warunkiem umożliwiającym zwiększenie produkcji.

\section{Wnioski}

W analizowanym okresie 2008-2021 zwiększyła się liczba odmian roślin bobowatych w Krajowym Rejestrze (KR), dotyczy to szczególnie soi. Zmniejszyła się liczba rejestrowanych odmian grochu, bobiku, łubinu białego i wyki. Dominują odmiany krajowej hodowli, ale udział odmian zagranicznych wzrasta i wynosi $24 \%$, a soi $68 \%$.

1. Plony poszczególnych gatunków nie zmieniały się znacząco, a w przypadku łubinów uprawianych na słabszych glebach, można stwierdzić spadek ich plonów w ostatnich latach. Występuje też duża zmienność plonowania w latach.

2. Najplenniejszymi gatunkami są bobik oraz nieznacznie ustępujący mu groch, odpowiednie do uprawy na lepszych stanowiskach i w intensywniejszej technologii. Plony łubinu wąskolistnego i żółtego testowanych na słabszych glebach oraz przy niższym poziomie nawożenia, były znacznie mniejsze. W ostatnich latach wzrastały jedynie plony soi.

3. W zobiektywizowanej ocenie, czyli po wyeliminowaniu wpływu niekontrolowanych czynników środowiskowych, stwierdzono niewielkie, ale istotne wzrosty plonów nasion i białka. Średni roczny przyrost plonów mieścił się w przedziale od 6,6 kg nasion na hektar dla łubinu żółtego do 40,2 kg nasion na hektar dla soi. Jedynie wartości wykazane dla soi były zbliżone do analogicznych wartości uzyskiwanego wzrostu potencjału plonowania zbóż. Efektem tego są rosnące różnice między potencjalnymi możliwościami plonowania zbóż i bobowatych.

4. Wykorzystanie istniejącego potencjału plonowania roślin bobowatych w praktyce jest lepsze niż potencjału zbóż. Jest to jednak za mało dla utrzymania a tym bardziej poprawienia ich konkurencyjności, co jest niezbędnym warunkiem umożliwiającym zwiększenie krajowej produkcji białka roślinnego. 


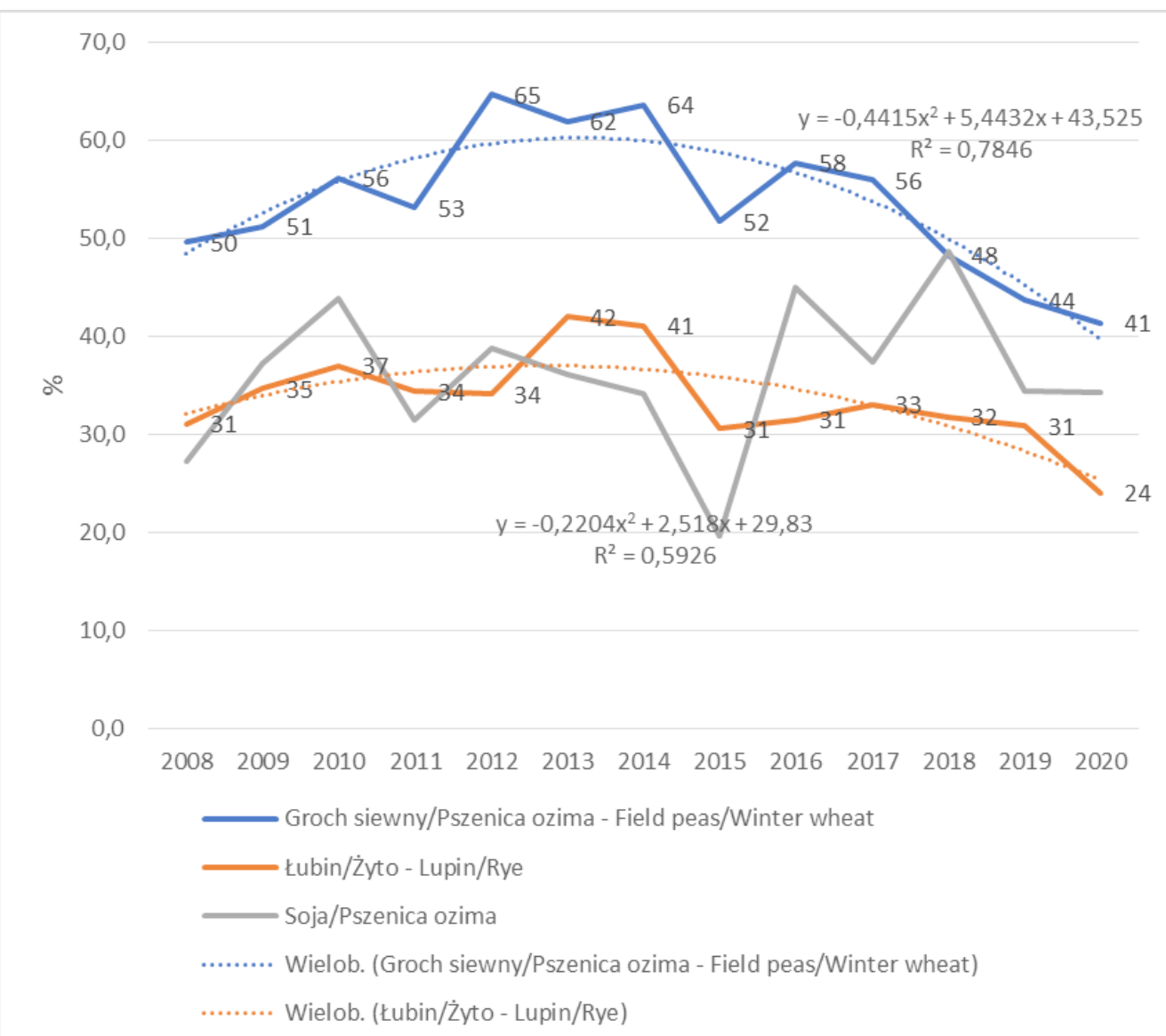

Rys. 4 Relacja plonów gatunków roślin bobowatych grubonasiennych do plonów zbóż w latach 2008-2020 w Porejestrowych badaniach odmianowych (PDO).

Fig. 4 Relation of the yields of grain legume species to the yields of cereals in 2008-2020 in the Post-Registration Variety Testing trials (PDO).

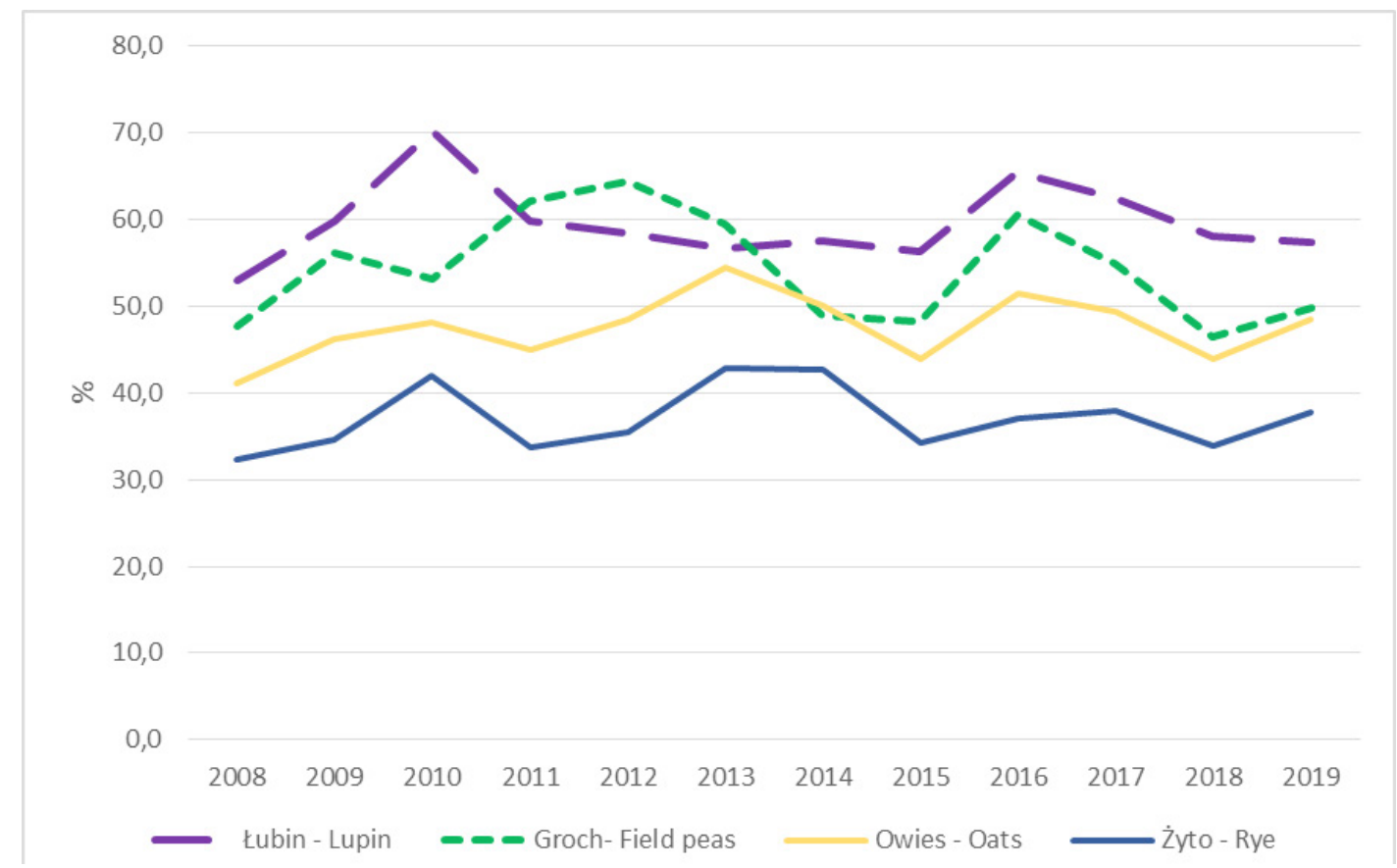

Rys. 5 Wykorzystanie potencjału plonowania roślin bobowatych grubonasiennych zbóż w latach 2008-2020 na podstawie wyników z doświadczeń (PDO) i z produkcji (GUS).

Fig. 5. Utilization of the yield potential of grain legumes in 2008-2020 based on the results of Post-Registration Variety Testing trials (PDO) and production (GUS). 


\section{Literatura}

COBORU (2006)-2020. Wyniki Porejestrowych Doświadczeń Odmianowych. Rośliny bobowate.

Felipe M., Gerde J. A., and Rotundo J. L. (2016). Soybean Genetic Gain in Maturity Groups III to V in Argentina from 1980 to 2015, Crop Sci. 56:1-12, https://doi: 10.2135/cropsci2016.04.0214

Feyerherm A. M., Kemp K. E., Paulsen G. M. (1989). Genetic contribution to increased wheat yields in the USA between 1979 and 1984 Agronomy Journal 81: 242-245.

Florek J. (2017). Możliwości wykorzystania roślin strączkowych do produkcji pasz w Polsce. Roczniki Naukowe Stowarzyszenia Ekonomistów Rolnictwa i Agrobiznesu, XIX (4), 40-45.

Gacek E. (2017). Potencjał hodowlany i osiągnięcia polskiej hodowli roślin rolniczych. Biul. IHAR 282, 151-160.

GUS 2005-2020. Roczniki Statystyczne.

Jezierny D., Mosenthin R., Bauer E. (2010). The use of grain legumes as a protein source in pig nutrition: A review. Animal Feed Science and Technology 157 (3-4), 111-128. https://doi.org/10.1016/j.anifeedsci.2010.03.001

Kapusta F. (2017). Rola roślin strączkowych w rolnictwie polskim. Zagadnienia Doradztwa Rolniczego 1: 68-78.

Krzymuski J., Laudański Z., Oleksiak T. (1993). Metody oceny postępu genetycznego, Zesz. Nauk. AR we Wrocławiu, Rolnictwo Nr 223: 49-56.
Małecka-Jankowiak I., Blecharczyk A., Sawińska Z., Waniorek W. (2018). Wpływ następczy łubinu i grochu na plonowanie pszenicy ozimej w zależności od uprawy roli i nawożenia azotem. Fragm. Agron., 35 (4), 67-79. DOI: $10.26374 /$ fa. 2018.35 .43

Prusiński J. (2007). Postęp biologiczny w hodowli i uprawie grochu siewnego i bobiku. Fragmenta Agronomica XXIV, $\mathrm{Nr} 4$ (96),

Sońta M., Rekiel A. (2020). Legumes - use for nutritional and feeding purposes. J. Elem., 25 (3), 835-849. DOI: 10.5601/jelem.2020.25.1.1953

Stagnari F., Maggio A., Galieni A., Pisante M. (2017). Multiple benefits of legumes for agriculture sustainability: an overview. Chem. Biol. Technol. Agric. 4 (2). https:// doi.org/10.1186/s40538-016-0085-1

Stojšin D., Matson K.W., Leitz R.A. (2014). Sustainable Agriculture and Soybean Breeding: Contribution of Soybean Yield Increase to Sustainable Agriculture. In: Songstad D., Hatfield J., Tomes D. (eds) Convergence of Food Security, Energy Security and Sustainable Agriculture. Biotechnology in Agriculture and Forestry, vol 67. Springer, Berlin, Heidelberg. https://doi. org/10.1007/978-3-642-55262-5_9

Święcicki W. (1993). Wybrane zagadnienia genetyki i hodowli łubinu. Łubin w gospodarce i życiu człowieka. Materiały Konferencyjne. PTŁ Poznań: 23-39. 